\title{
Can Vitamins, as Epigenetic Modifiers, Enhance Immunity in COVID-19 Patients with Non-communicable Disease?
}

\author{
Varsha Singh ${ }^{1}$ \\ Published online: 13 July 2020 \\ (C) Springer Science+Business Media, LLC, part of Springer Nature 2020
}

\begin{abstract}
Purpose of Review The highly infectious transmissible disease, the novel SARS-CoV-2, causing the coronavirus disease (COVID-19), has a median incubation time of 5 to 15 days. The symptoms vary from person to person and many are "hidden carriers." Few people experience immediate reaction and even death within $48 \mathrm{~h}$ of infection. However, many show mild to chronic symptoms and recover. Nevertheless, the death rate due to COVID-19 transmission is high especially among patients with non-communicable diseases. The purpose of this review is to provide evidence to consider vitamins as epigenetic modifiers to enhance immunity and reduce inflammatory response in COVID-19 patients with non-communicable diseases.

Recent Findings Clinical evidence has suggested the risk of getting infected is high among individuals with non-communicable diseases such as cardiovascular disease, type- 2 diabetes, cancer, acute respiratory distress syndrome, and renal disease, as well as the elderly with high mortality rate among the cohort. The impact is due to an already compromised immune system of patients. Every patient has a different response to COVID-19, which shows that the ability to combat the deadly virus varies individually. Thus, treatment can be personalized and adjusted to help protect and combat COVID-19 infections, especially in individuals with non-communicable diseases.

Summary Based on current published scientific and medical evidence, the suggestions made in this article for combination of vitamin therapy as epigenetic modifiers to control the unregulated inflammatory and cytokine marker expressions, further needs to be clinically proven. Future research and clinical trials can apply the suggestions given in this article to support metabolic activities in patients and enhance the immune response.
\end{abstract}

Keywords COVID-19 $\cdot$ Vitamin $\cdot$ Pandemic $\cdot$ Non-communicable disease $\cdot$ Immunotherapy

\section{Introduction}

After December 2019, the ongoing death rate due to a novel flu-like coronavirus disease (COVID-19) pandemic has suddenly spread aggressively and continues to increase exponentially. The human to human COVID-19 (SARS-CoV2) is transmitted through the species barrier due to close contact, causing symptoms including extreme fever, cough, pneumonia, acute respiratory disorders, multi-organ failure, and eventually, high mortality among infected patients [1]. The

This article is part of the Topical Collection on Functional Foods

Varsha Singh

varsha.singh@chitkara.edu.in

1 Centre for Life Sciences, Chitkara School of Health Sciences, Chitkara University, Punjab 140401, India symptoms appear between 5 and 15 days. The "hidden" human carriers also risk the transmission of the virus between close contacts [2]. Nonetheless, the exact mechanism of transmission still needs to be checked clinically. COVID-19, a highly contagious transmissible disease, has proven to be resistant to the body's own defense mechanism. With corona cases increasing globally, important biological and clinical trends among patients with special conditions are being reported.

The high mortality rate of COVID-19 is being largely observed in patients with non-communicable diseases (NCDs) including cardiovascular disease (CVD), long-term type-2 diabetes (T2D), and renal disease, together along with the elderly population with/without history of NCDs [3, 4]. More findings are needed; however, to analyze why vulnerable populations are affected and to define clearly the connection between COVID-19 and patients with NCDs. The COVID-19 virus invades the respiratory tract cells and causes thick mucus 
formation leading to lung damage and the septic shock which was also observed in patients with vulnerability with acute respiratory distress symptoms (ARDS) [5]. Previous studies clinically consider a compromised immune system for NCD patients (including smokers and non-smokers) [6, 7]. The affected immune system has a significant effect on the cell's metabolic activity and gene expression [8]. Just as NCDs strike people with reduced resistance or impaired health condition, the "opportunistic" COVID-19 has mainly impacted patients with NCDs with a compromised immune system [9].

Because NCDs are the world's leading cause of death, patients receive micronutrient therapy strategies to treat undernutrition, improve immunity, and prevent infection [10,11]. At the UN High-Level Meeting on the Prevention and Control of Non-Communicable Diseases, held in New York, USA in September 2011, prevention strategies for NCDs have already been addressed with a view to prenatal nourishment, improving diet and nutrients, and preventing undernutrition and infections. Since NCDs are highly dependent on the individual lifestyle [12], dietary intake and environmental conditions and exposure often play a role in each person's personal response to a specific disease [13]. The European Non-communicable Disease Prevention and Control Office (NCD Office) of the World Health Organization (WHO), in cooperation with the Russian Federation Ministry of Health, has developed a plan to tackle the "customized" approach to prevention and control of NCDs. Treatment of patients can be personalized to help develop a model that characterizes the phenotype and genotype of patients for a more targeted, life-saving treatment due to specific medications and treatment. It is noteworthy that this individualized approach has a potential of obtaining positive results for COVID-19 patients, if individuals are thoroughly tested and treated according to their unique metabolic function.

For COVID-19, which largely is controlling the molecular/ genetic immune system of the host, its complete causal relationship has not been identified with the immune system. However, changes in COVID-19 patients along with the physiological factors can be seen in affected body tissue, particularly in the lungs that contribute towards lung injury and ultimately cardiac arrest $[14,15]$. Circulative factors such as interleukin factors (IL-4, IL-6, IL-10, and IL-13) and interferons (IFN- $\gamma$ ), tumor necrosis factor (TNF- $\alpha$ ) nuclear factor- $\mathrm{kB}$ (NF-kB), cytotoxic $\mathrm{T}$ lymphocyte-associated antigen-4 (CTLA4), and Toll-like receptors-4 (TLR-4) are typically seen in patients with the majority of major NCDs [16-18]. The infection may be targeting gene transcription and regulation of inflammatory markers and chromatin structure machinery of NCD patients [19].

In addition to the body's vital functions, vitamins have an important role to play in immunopathological and physiological response of the body. Studies have shown effective treatment for patients with the addition of vitamins and the reduction of inflammatory circulatory markers [20]. The highly regulated machinery depends on these epigenetic modifiers obtained mainly from the diet [21]. As gene regulation and suppression is evident in various vitamin-regulated mechanisms that control epigenetic changes such as DNA methylation, histone modification, and post-translation modifications $[22,23]$, inflammatory markers are widely known to be controlled by such micronutrients as well [24-27]. Both fat- and water-soluble vitamins have proven to be crucial to epigenetic modification to strengthen the immune system and cell growth of an organism as important micronutrients for patients with NCDs [28].

Because there is currently no clinically approved COVID19 medication or vaccine available, attempts to improve the immunity of NCD patients with COVID-19, vitamin deficiencies should also be tested. The tests would fulfill the requirement to track and regulate proper metabolic activity and immune reactions towards enhanced inflammatory markers. Clinical evidence also suggests that vitamin $\mathrm{C}$ is beneficial against SARS coronavirus [29] and COVID-19 is 82\% comparable with SARS-CoV [30, 31]. There is also an urgent need to reduce high mortality rates due to COVID-19 and concentrate on an innovative and individual patient strategy to boost therapy effectiveness. The general associations and conclusions identified and reviewed suggest the value of micronutrients to public health experts, and so it is strongly recommended that clinical professionals investigate the alternative treatment further.

\section{Immune Response, Vitamin Deficiency in NCDs, and Relation to COVID-19}

Multiple pathways are activated in NCDs. Patients with NCDs are more prone to infections which can be related with high mortality rates [32] as also observed in COVID-19 patients. Mechanisms may be linked to vitamin deficiency and its effects that lead to impaired immune response. Therefore, early intervention of both clinical and individual preventive and control strategies to help prevent the spread of the infection is important, particularly in people with compromised immunity. The widespread distribution of COVID-19 has shown a high mortality rate in NCDs and in people with low immunity. A new, holistic approach to providing people with the right vitamin doses can lead to more effective and individual centric therapy. Scientific and clinical data show that immune responses in CVD, T2D, ARDS, cancer, renal diseases, and autoimmune disorders are strongly compromised. Genetic control of inflammatory markers should be considered as clinically relevant circulatory markers for COVID-19 in individuals with the abovementioned NCDs. The fact that vitamins have been recognized as epigenetic modifications in gene expression in methylation, citrullination, acetylation, and 
Table 1 Type of NCDs with respective inflammatory response markers and vitamin deficiencies

\begin{tabular}{|c|c|c|c|}
\hline Type of NCD & Enhanced inflammatory markers & Vitamin deficiency generally observed & Ref. \\
\hline \multirow[t]{3}{*}{ CVD } & CRP & Vitamin D & {$[20,34-42]$} \\
\hline & IL-6 & & \\
\hline & TLR4 & & \\
\hline \multirow[t]{5}{*}{$\mathrm{T} 2 \mathrm{D}$} & IL-4 & Vitamin $\mathrm{B}_{9}$ & {$[43]$} \\
\hline & IL-10 & Vitamin $\mathrm{B}_{12}$ & \\
\hline & IL-13 & Vitamin A & \\
\hline & IFN- $\gamma$ & Vitamin C & \\
\hline & TNF- $\alpha$ & Vitamin E & \\
\hline \multirow[t]{2}{*}{ ARDS } & $\mathrm{NF}-\mathrm{kB}$ & Vitamin $\mathrm{D} / \mathrm{E}$ & {$[44-47]$} \\
\hline & $\mathrm{GR} \alpha$ & Vitamin E & \\
\hline \multirow[t]{2}{*}{ Cancer } & CTLA4 & Vitamin $\mathrm{B}_{12}$ & {$[48-50]$} \\
\hline & PD1 & Vitamin D & \\
\hline \multirow[t]{3}{*}{ Renal diseases } & T lymphocytes & $\begin{array}{l}\text { Vitamin E } \\
\text { Vitamin D }\end{array}$ & {$[51]$} \\
\hline & B lymphocytes & Vitamin A & \\
\hline & Th1/Th2 ratio & & \\
\hline
\end{tabular}

$N C D$, non-communicable disease; $C V D$, cardiovascular disease; $T 2 D$, type-2-diabetes; $A R D S$, acute respiratory distress syndrome phosphorylation [33] can be clinically associated. As can be seen in Table 1, clinical evidence suggests that NCD patients are highly specific with immune sensitive molecules and are deficient in certain types of vitamins [52].

Fatal outcomes have been found in COVID-19 patients causing acute myocardial injury (MI) and chronic damage. Epidemiological data consistently show an increased risk of CRP, TLR4, and IL-6 with subsequent cardiovascular events [34-36]. The CVD incidence history shows an altered polymorphism of the $-174 / \mathrm{GC}$ that suggests a possibility for CV event in patients along with the SNP variant of the CRP gene with higher plasma levels [37]. On the other hand, the circulating TLR-4 signal also promotes myocardial infarction. Active vitamin D metabolite signaling pathways control various interleukin factor including IL-6, CRP, and TLR [53]. The epigenetics of this clearly illustrates that vitamin D deficiency is observed in CVD patients [38] with other promoter elements also regulated by vitamins $\mathrm{A}, \mathrm{E}$, and $\mathrm{B}_{9 / 12}$. It is worth noting that COVID-19 increases the risk of CVD among patients and may be causing over-expression of immune response factors that influence the risk of $\mathrm{CV}$ events for COVID-19 patients due to vitamin deficiencies. T2D individuals have significant levels of IL-4, IL-10, IL-13, and IFN- $\gamma$ and TNF- $\alpha$ [54]. Individuals having a highly compromised immune system can be explained due to impaired insulin secretion, over-stressed cell organelles such as endoplasmic reticulum and oxidative stress, and glucotoxicity [55]. The cellular stress in T2D induces inflammatory response due to specific cytokines and chemokines [56]. In addition to T2D patients being prone to infections, the patients suffer from vitamins $\mathrm{B}_{9}$ (folic acid), $\mathrm{B}_{12}, \mathrm{~A}, \mathrm{C}$, and $\mathrm{E}$ deficiencies [43], hence absence in maintenance of chromatin structure of cell genome, increased apoptosis, and absence of protein integrity. Overall, there is complete absence of epigenetic control of cellular processes in T2D individuals making them susceptible to infectious diseases.

Scientific evidence shows ARDS patients to express $\mathrm{NF}-\mathrm{KB}$ and GR $\alpha$ leading to dysregulated mechanisms which leads to up- or down-regulation of various pro-inflammatory mediators and increased oxidative stress [57]. Transcriptional mediators such as NF- $\mathrm{KB}$ expressed in ARDS are attenuated by vitamin $C$; however, vitamin $\mathrm{D}$ and $\mathrm{E}$ deficiency in ARDS patients also indicate absence of epigenetic control on gene transcription due to possible absence of proper DNA methylation and histone modification status in the cells [44] which may contribute towards dysregulated transcriptional mechanism. Patients with COVID-19 tend to develop severe immune activation in lungs [14] and hence pneumonia. The clinical link between active inflammatory pathways in ARDS and the vitamin deficiency clearly indicates why COVID-19 causes high mortality in patients with chronic lung diseases.

Epidemiological data confirm higher prevalence of cancer patients with COVID-19. Cancer patients with history of immunosuppressants who are COVID-19 positive are also facing worse outcomes [58]. CTL4A and PD1 are two of the main immune adaptive response regulators that inhibit the normal $\mathrm{T}$ regulatory cell in cancer-stricken patients. Inhibition of both tumor markers resulted in clinical trials to provide antiCTL4A and anti-PD1 antibodies for cancer therapy, which may be useful for regulating a $\mathrm{T}$ cell proliferation signaling pathway $[59,60]$. The possible balance between controlling CTL4A and PD1 expression [48], as well as providing vitamin 
Table 2 Immune-responsive inflammatory markers and their epigenetic mechanism of gene regulation by different vitamins

\begin{tabular}{|c|c|c|c|}
\hline $\begin{array}{l}\text { Type of } \\
\text { inflammatory } \\
\text { marker }\end{array}$ & $\begin{array}{l}\text { Type of vitamin } \\
\text { controlling } \\
\text { epigenetic } \\
\text { mechanism }\end{array}$ & $\begin{array}{l}\text { Vitamin-regulated } \\
\text { epigenetic mechanism }\end{array}$ & Ref \\
\hline CRP & Vitamin D & $\begin{array}{l}\text { DNA methyl } \\
\text { transferase/histone } \\
\text { deacetylase of gene }\end{array}$ & {$[66-68]$} \\
\hline TLR4 & Vitamin E & $\begin{array}{l}\text { Inhibition of MAPK } \\
\text { activation }\end{array}$ & \\
\hline \multirow[t]{4}{*}{ IL-6 } & Vitamin $\mathrm{B}_{9}$ & Promoter methylation & \\
\hline & Vitamin $\mathrm{B}_{12}$ & $\begin{array}{l}\text { Decrease in epidermal } \\
\text { growth factor (EGF) } \\
\text { synthesis }\end{array}$ & \\
\hline & Vitamin A & $\begin{array}{l}\text { Regulating cell-mediated } \\
\text { and humoral } \\
\text { components/ lack of B } \\
\text { cell switching and } \\
\text { proliferation factors }\end{array}$ & \\
\hline & Vitamin D & $\begin{array}{l}\text { DNA methyl } \\
\text { transferase/histone } \\
\text { deacetylase of gene }\end{array}$ & [69-73] \\
\hline IL-4 & Vitamin $\mathrm{D}_{3}$ & $\begin{array}{l}\text { Inhibit the functional } \\
\text { differentiation of Th1 } \\
\text { cells }\end{array}$ & \\
\hline IL-10 & Vitamin D & $\begin{array}{l}\text { DNA methyl } \\
\text { transferase/histone } \\
\text { deacetylase of gene }\end{array}$ & \\
\hline IL-13 & Vitamin D & $\begin{array}{l}\text { Alteration of } \mathrm{Th} 1 / \mathrm{Th} 2 \\
\text { expression/production of } \\
\text { IgE }\end{array}$ & \\
\hline IFN- $\gamma$ & Vitamin D & Hydroxylase activity & \\
\hline TNF- $\alpha$ & Vitamin C & $\begin{array}{l}\text { Methylation/demethylation } \\
\text { cycle/histone } \\
\text { modification }\end{array}$ & \\
\hline \multirow[t]{2}{*}{$N F-\kappa B$} & Vitamin A & $\begin{array}{l}\text { Retinoid X receptor binds } \\
\text { RA response elements } \\
\text { (RAREs) and regulates } \\
\text { gene promoter }\end{array}$ & [74-77] \\
\hline & Vitamin E & $\begin{array}{l}\text { Enhances binding of } \\
\mathrm{NF}-\mathrm{kB} \text { to the } \\
\text { corresponding gene } \\
\text { promoters }\end{array}$ & \\
\hline $\mathrm{GR} \alpha$ & Vitamin D & $\begin{array}{l}\text { DNA methyl } \\
\text { transferase/histone } \\
\text { deacetylase of gene }\end{array}$ & \\
\hline CTLA4 & Vitamin D & $\begin{array}{l}\text { Development of regulatory } \\
\mathrm{T} \text { cells by antagonizing } \\
\text { inflammatory outcomes } \\
\text { and promotes regulation }\end{array}$ & {$[78-80]$} \\
\hline PD1 & Vitamin D & $\begin{array}{l}\text { DNA methyl } \\
\text { transferase/histone } \\
\text { deacetylase of gene }\end{array}$ & \\
\hline \multirow[t]{3}{*}{$\begin{array}{l}\text { T } \\
\text { lympho- } \\
\text { cytes }\end{array}$} & Vitamin $\mathrm{D}_{3}$ & $\begin{array}{l}\text { DNA methyl } \\
\text { transferase/histone } \\
\text { deacetylase of gene }\end{array}$ & {$[73$} \\
\hline & 81-86] & & \\
\hline & Vitamin E & $\begin{array}{l}\text { Regulating gene expression } \\
\text { in response to } \mathrm{T} \text { cell } \\
\text { stimulation }\end{array}$ & \\
\hline Vitamin $B_{12}$ & $\begin{array}{l}\text { Relating to } \\
\mathrm{CD} 8^{+} \text {cells }\end{array}$ & & \\
\hline
\end{tabular}

Table 2 (continued)

\begin{tabular}{|c|c|c|c|}
\hline $\begin{array}{l}\text { Type of } \\
\text { inflammatory } \\
\text { marker }\end{array}$ & $\begin{array}{l}\text { Type of vitamin } \\
\text { controlling } \\
\text { epigenetic } \\
\text { mechanism }\end{array}$ & $\begin{array}{l}\text { Vitamin-regulated } \\
\text { epigenetic mechanism }\end{array}$ & Ref \\
\hline & $\begin{array}{l}\text { and the NK } \\
\text { cell system }\end{array}$ & & \\
\hline \multirow[t]{2}{*}{$\begin{array}{l}\text { B lympho- } \\
\text { cytes }\end{array}$} & Vitamin A & $\begin{array}{l}\text { Retinoid X receptor binds } \\
\text { RA response elements } \\
\text { (RAREs) and regulates } \\
\text { gene promoter }\end{array}$ & \\
\hline & Vitamin D & $\begin{array}{l}\text { DNA methyl } \\
\text { transferase/histone } \\
\text { deacetylase of gene }\end{array}$ & \\
\hline \multirow[t]{2}{*}{ Th1/Th2 ratio } & Vitamin A & $\begin{array}{l}\text { Binding of retinol to } \\
\text { nucleosome complex on } \\
\text { RA-target genes }\end{array}$ & \\
\hline & Vitamin D & $\begin{array}{l}\text { DNA methyl } \\
\text { transferase/histone } \\
\text { deacetylase of gene }\end{array}$ & \\
\hline
\end{tabular}

D supplements [61], has shown increased T-lymphocytic proliferation, expressing high VDR in cancer patients triggering the $T$ cell differentiation immune response. The evidence clearly shows the degree of clinical infection manifestations in cancer patients with positive COVID-19 test.

Fatalities in kidney patients are also investigated, provided that COVID-19 patients with ongoing kidney and renal disease are controlled with a high degree of caution $[62,63]$. Signs of kidney dysfunction include elevated proteinuria, urea and serum potassium, hematuria, and other clinical comorbidity [64]. Patients with a history of failure of kidney disease develop inflammation which contributes to the activation of the adaptive immunity of increased $\mathrm{Th} 1 / \mathrm{Th} 2$ ratios and to $\mathrm{T}$ and $\mathrm{B}$ lymphocyte autoantibodies [51]. Infectious pathogens may easily enter the kidney patients. This possibility should also be timely addressed in COVID-19 patients to prevent end-stage renal diseases (ESRD). In kidney patients, vitamin $\mathrm{D}$ is discovered to be deficient, putting them at risk of $\mathrm{CKD}$ and hyperparathyroidism. The vitamin suppresses most of the adaptive immune system which can play an important role in protecting the host against first-line defense invasion of COVID-19. In the COVID-19 patients with kidney transplant [65], vitamin D may prove effective and this may also prevent graft rejection and regulate $\mathrm{Th} 1 / \mathrm{Th} 2$ ratios.

Micronutrient therapy to be considered and given should be individual centric and based upon time and dose-response manner. Vitamin therapy seems feasible at this time due to absence of the vaccine or medication available for care to prevent multiple organ failure and immunologic deaths among COVID-19-positive patients with NCD. Table 2 summarizes the vitamins that control the immunomodulatory elements and the mechanism of action. If the population receives the right dose of vitamins specific to NCD and inflammatory 
Table 3 Vitamin supplements recommended as alternate personalized therapy for NCD patients with COVID-19 to enhance the immune response of patients infected with SARSCoV2

\begin{tabular}{|c|c|c|}
\hline $\begin{array}{l}\text { Type of } \\
\text { NCD }\end{array}$ & $\begin{array}{l}\text { Vitamin supplement to be given to COVID-19-positive } \\
\text { patients with NCD }\end{array}$ & $\begin{array}{l}\text { If elderly, additional vitamin to be } \\
\text { provided [87] }\end{array}$ \\
\hline CVD & $\begin{array}{l}\text { Vitamin A } \\
\text { Vitamin D } \\
\text { Vitamin E } \\
\text { Vitamin } B_{12}\end{array}$ & Cobalamin (vitamin $\mathrm{B}_{12}$ ) \\
\hline $\mathrm{T} 2 \mathrm{D}$ & $\begin{array}{l}\text { Vitamin A } \\
\text { Vitamin C } \\
\text { Vitamin D } \\
\text { Vitamin E } \\
\text { Vitamin } B_{9} \\
\text { Vitamin } B_{12}\end{array}$ & Cobalamin (vitamin $\mathrm{B}_{12}$ ) \\
\hline ARDS & $\begin{array}{l}\text { Vitamin A } \\
\text { Vitamin D } \\
\text { Vitamin E }\end{array}$ & Cobalamin (vitamin $\mathrm{B}_{12}$ ) \\
\hline Cancer & $\begin{array}{l}\text { Vitamin A } \\
\text { Vitamin C } \\
\text { Vitamin D } \\
\text { Vitamin E } \\
\text { Vitamin } B_{12}\end{array}$ & Cobalamin (vitamin $B_{12}$ ) \\
\hline $\begin{array}{l}\text { Renal } \\
\quad \text { diseases }\end{array}$ & $\begin{array}{l}\text { Vitamin A } \\
\text { Vitamin D }\left(\mathrm{D}_{3}\right) \\
\text { Vitamin E } \\
\text { Vitamin } \mathrm{B}_{12}\end{array}$ & Cobalamin (vitamin $\mathrm{B}_{12}$ ) \\
\hline
\end{tabular}

$N C D$, non-communicable disease; $C V D$, cardiovascular disease; $T 2 D$, type-2-diabetes; $A R D S$, acute respiratory distress syndrome factors expressed, effects on respiratory health can be observed as DNA methylation, histone modification, and enzyme control, and the proper cell division of healthy cells can be regulated. This personalized therapy recommends a medical model that should characterize the COVID-19positive individuals for diagnosis based on the type of NCDs.

\section{Vitamin Therapy as a Personalized Approach}

Based on primary observation on previous evidences, the types of vitamin combinations which can be given to patients are shown in Table 3. Based on clinical evidence, the table combines the types of vitamins which can be selected to enhance the immunity of patients to reduce the inflammatory response in NCD patients. There is strong need for personalized treatment for COVID-19 patients suffering from NCD as an alternative therapy [88]. The compilation of literature, shown in Table 3 , citing clinical evidence for a potential vitamin link in the control of immune expression of inflammatory markers to treat an infectious pandemic [89], needs to be clinically validated. As vitamins regulate the epigenetic machinery, age, sex, smoking, ethnicity, and other environmental/lifestyle factors are also affected by changes to immune response. Several NCDs are driven by genomic instability, hypermethylation, and hypomethylation of promoter gene regions involved in immunological marker and element regulation. Treating vitamins as major epigenetic modifiers will prove to be an effective approach to customized treatment, particularly for COVID-19 patients with different background factors that could have contributed in the past to develop the specific NCD. Vitamin therapy can be an effective and safe treatment as a custom drug. In COVID-19 patients, the storm of inflammatory or cytokine factors should be tested by assessing patients for different inflammatory markers and vitamin deficiency. In order to provide a metabolism for an individual against vitamin deficiency, all individuals should be screened for specific immune cell reactions and the factors represented by the specific NCD. The combination will improve care and lead to a more personalized approach. An exhaustive review is also needed for other factors such as pregnancy and other medical conditions. This can be used as time progresses and new clinical data for COVID-19 patients are available.

\section{Conclusion}

This study can serve as a primary link to open ways to look at important facts to cure people, otherwise having compromised 
immune systems due to NCDs. This may include more studies and recommendation of personalized approach for patients to be treated. The benefit is that vitamin therapy has no side effect and has proven to be effective. The micronutrient combination is also recommended for the target population without NCD or help early in its prevention of infectious diseases for patients at risk for COVID-19. Other factors, such as smoking and drinking, should not be overlooked. This will also extend guidelines and policy changes to undernutrition and infections in low- and middle-income countries. Therefore, opportunistic infections can be better controlled in the future with low mortality rate, and vitamins can serve as useful epigenetic modifiers to genetically target and modify transcriptional and translational control of various inflammatory markers.

\section{Compliance with Ethical Standards}

Conflict of Interest The authors declare they have no conflict of interest.

Human and Animal Rights and Informed Consent This article does not contain any studies with human or animal subjects performed by any of the authors.

\section{References}

Papers of particular interest, published recently, have been highlighted as:

- Of importance

•. Of major importance

1. Herrick C. Syndemics of COVID-19 and "pre-existing conditions". Somatosphere. http://somatosphere.net/2020/syndemics-of-covid19-and-pre-existing-conditions.html/. Accessed 30 Mar. 2020.

2. Yang Y, Peng F, Wang R, Guan K, Jiang T, Xu G, et al. The deadly coronaviruses: the 2003 SARS pandemic and the 2020 novel coronavirus epidemic in China. J Autoimmun. 2020:102434. https://doi. org/10.1016/j.jaut.2020.102434

3. Thierry A, Roch B. NETs by-products and extracellular DNA may play a key role in COVID-19 pathogenesis: incidence on patient monitoring and therapy. Preprints. 2020;2020040238.

4. Oliver L. Inequality affects the COVID-19 Pandemic. https://www. weforum.org/agenda/2020/03/coronavirus-pandemic-inequalityamong-workers/. Accessed 2nd Apr 2020.

5. Han N, Shen Y. S100A12 promotes inflammation and cell apoptosis in sepsis induced ARDS via activation of NLRP3 inflammasome signaling. Mol Immunol. 2020;122:38-48.

6. Kastelein TE, Duffield R, Marino FE. Acute immune-inflammatory responses to a single bout of aerobic exercise in smokers; the effect of smoking history and status. Front Immunol. 2015;6:634.

7. Feldman C, Anderson R. Cigarette smoking and mechanisms of susceptibility to infections of the respiratory tract and other organ systems. J Inf Secur. 2013;67(3):169-84.

8. Knight JA. Free radicals, antioxidants, and the immune system. Ann Clin Lab Sci. 2000;30(2):145-58.

9. Pal R, Bhadada SK. COVID-19 and non-communicable diseases. Postgrad Med J. 2020;96:429-30. https://doi.org/10.1136/ postgradmedj-2020-137742.
10. Meydani A, Ahmed T, Meydani SN. Aging, nutritional status, and infection in the developing world. Nutr Rev. 2005;63(7):233-46.

11. Abba A, Fokam J, Kamgaing RS, Yimga JF, Kaé AC, Nka AD, et al. Correlation between the immuno-virological response and the nutritional profile of treatment-experienced HIV-infected patients in the East region of Cameroon. bioRxiv. 2020. https://doi.org/10. 1101/2020.02.11.943621.

12. Bilal HS, Akhtar U, Chul SW, Lee S. Just in time intervention for personalized healthcare: behavior-context based intervention adaptation. In 2020 International Conference on Information Networking (ICOIN) 2020:64-69; IEEE.

13. Paez D, Giammarile F, Orellana P. Nuclear medicine: a global perspective. Eur J Nucl Med Mol Imaging. 2020;47:1615-9. https://doi.org/10.1007/s00259-020-04825-8.

14. Chu H, Chan JF, Wang Y, Yuen TT, Chai Y, Hou Y, et al. Comparative replication and immune activation profiles of SARS-CoV-2 and SARS-CoV in human lungs: an ex vivo study with implications for the pathogenesis of COVID-19. Clin Infect Dis. 2020. https://doi.org/10.1093/cid/ciaa410.

15. Clerkin KJ, Fried JA, Raikhelkar J, Sayer G, Griffin JM, Masoumi A, Jain SS, Burkhoff D, Kumaraiah D, Rabbani L, Schwartz A. Coronavirus disease 2019 (COVID-19) and cardiovascular disease. Circulation. 2020;141(20):1648-55.

16. Shi Y, Wang Y, Shao C, Huang J, Gan J, Huang X, et al. COVID19 infection: the perspectives on immune responses. Cell Death Differ. 2020;7:1451-4.

17. Cooper AC, Mikhail A, Lethbridge MW, Kemeny DM, Macdougall IC. Increased expression of erythropoiesis inhibiting cytokines (IFN- $\gamma$, TNF- $\alpha$, IL-10, and IL-13) by T cells in patients exhibiting a poor response to erythropoietin therapy. Clin J Am Soc Nephrol. 2003;14(7):1776-84.

18. Kumar A, Begum N, Prasad S, Agarwal S, Sharma S. IL-10, TNF$\alpha \&$ IFN- $\gamma$ : potential early biomarkers for preeclampsia. Cell Immunol. 2013;283(1-2):70-4.

19. Jha HC, Divya A, Prasad J, Mittal A. Plasma circulatory markers in male and female patients with coronary artery disease. Heart Lung. 2010;39(4):296-303.

20. Zittermann A, Schleithoff SS, Koerfer R. Putting cardiovascular disease and vitamin D insufficiency into perspective. Br J Nutr. 2005;94(4):483-92.

21. Anderson OS, Sant KE, Dolinoy DC. Nutrition and epigenetics: an interplay of dietary methyl donors, one-carbon metabolism and DNA methylation. J Nutr Biochem. 2012;23(8):853-9.

22. Herceg Z. Epigenetics and cancer: towards an evaluation of the impact of environmental and dietary factors. Mutagenesis. 2007;22(2):91-103.

23. Kouzarides T. Chromatin modifications and their function. Cell. 2007;128(4):693-705.

24. Wamberg L, Kampmann U, Stødkilde-Jørgensen H, Rejnmark L, Pedersen SB, Richelsen B. Effects of vitamin D supplementation on body fat accumulation, inflammation, and metabolic risk factors in obese adults with low vitamin D levels - results from a randomized trial. Eur J Intern. 2013;24(7):644-9.

25. Shea MK, Booth SL, Massaro JM, Jacques PF, D'Agostino RB Sr, Dawson-Hughes B, et al. Vitamin K and vitamin D status: associations with inflammatory markers in the Framingham Offspring Study. Am J Epidemiol. 2008;167(3):313-20.

26. Stubbs JR, Idiculla A, Slusser J, Menard R, Quarles LD. Cholecalciferol supplementation alters calcitriol-responsive monocyte proteins and decreases inflammatory cytokines in ESRD. Clin J Am Soc Nephrol. 2010;21(2):353-61.

27. Piyathilake CJ, Suguna Badiga PP, Vijayaraghavan K, Vedantham $\mathrm{H}$, Sudula M, Sowjanya P, et al. Indian women with higher serum concentrations of folate and vitamin B12 are significantly less likely to be infected with carcinogenic or high-risk (HR) types of human papillomaviruses (HPVs). Int J Women's Health. 2010;2:7. 
28. Ong TP, Pérusse L. Impact of nutritional epigenomics on disease risk and prevention: introduction. Lifestyle Genomics. 2011;4(5): 245-7.

29. Hemila H. Vitamin C and SARS coronavirus. J Antimicrob Chemother. 2003;52:1049-50.

30. Zhang N, Wang L, Deng X, Liang R, Su M, He C, Hu L, Su Y, Ren $\mathrm{J}, \mathrm{Yu}$ F, Du L. Recent advances in the detection of respiratory virus infection in humans. J Med Virol. 2020;92(4):408-17.

31. Chan JF, et al. Genomic characterization of the 2019 novel humanpathogenic coronavirus isolated from a patient with atypical pneumonia after visiting Wuhan. Emerg Microbes Infect. 2020;9:22136.

32. Ogoina D, Onyemelukwe GC. The role of infections in the emergence of non-communicable diseases (NCDs): compelling needs for novel strategies in the developing world. J Infect Public Health. 2009;2:14-29.

33. Ducasse M, Brown MA. Epigenetic aberrations and cancer. Mol Cancer. 2006;5(1):60.

34. Danesh J, Wheeler JG, Hirschfield GM, Eda S, Eiriksdottir G, Rumley A, et al. C-reactive protein and other circulating markers of inflammation in the prediction of coronary heart disease. $\mathrm{N}$ Engl J Med. 2004;350(14):1387-97.

35. Vabulas RM, Ahmad-Nejad P, Ghose S, Kirschning CJ, Issels RD, Wagner H. HSP70 as endogenous stimulus of the Toll/interleukin-1 receptor signal pathway. J Biol Chem. 2002;277:15107-12.

36. Spoto B, Mattace-Raso F, Sijbrands E, Leonardis D, Testa A, Pisano A, et al. Association of IL-6 and a functional polymorphism in the IL-6 gene with cardiovascular events in patients with CKD. Clin J Am Soc Nephrol. 2015;10(2):232-40.

37. Lange LA, Carlson CS, Hindorff LA, Lange EM, Walston J, Durda $\mathrm{JP}$, et al. Association of polymorphisms in the CRP gene with circulating C-reactive protein levels and cardiovascular events. JAMA. 2006;296(22):2703-11.

38. Judd S, Tangpricha V. Vitamin D deficiency and risk for cardiovascular disease. Circulation. 2008;117(4):503.

39. Humenikova L, Gates G. Relation between C-reactive protein and serum and dietary antioxidants in older adults at increased risk for cardiovascular disease. J Nutr Elder. 2005;24(4):23-37.

40. Zhang FF, Santella RM, Wolff M, Kappil MA, Markowitz SB, Morabia A. White blood cell global methylation and IL-6 promoter methylation in association with diet and lifestyle risk factors in a cancer-free population. Epigenetics. 2012;7(6):606-14.

41. Chang G, Zhuang S, Seyfert HM, Zhang K, Xu T, Jin D, et al. Hepatic TLR4 signaling is activated by LPS from digestive tract during SARA, and epigenetic mechanisms contribute to enforced TLR4 expression. Oncotarget. 2015;6(36):38578-90.

42. Candore G, Aquino A, Balistreri CR, Bulati M, Di Carlo D, Grimaldi MP, et al. Inflammation, longevity, and cardiovascular diseases: role of polymorphisms of TLR4. Ann N Y Acad Sci. 2006;1067(1):282-7.

43. Valdés-Ramos R, Ana Laura GL, Beatriz Elina MC, Alejandra Donaji BA. Vitamins and type 2 diabetes mellitus. Endocr Metab Immune Disord Drug Targets. 2015;15(1):54-63.

44. Banerjee A, Panettieri RA. Vitamin D modulates airway smooth muscle function. In Vitamin D and the Lung. In Humana Press, Totowa, NJ; 2012. pp. 127-150.

45. Meduri G, Cr Y. Systemic inflammation-associated glucocorticoid resistance and outcome of ARDS. Ann N Y Acad Sci. 2004;1024(1):24-53.

46. Xystrakis E, Kusumakar S, Boswell S, Peek E, Urry Z, Richards $\mathrm{DF}$, et al. Reversing the defective induction of IL-10-secreting regulatory $\mathrm{T}$ cells in glucocorticoid-resistant asthma patients. $\mathrm{J}$ Clin Invest. 2006;116(1):146-55.

47. Richard CH, Lemonnier FR, Thibault MA, Couturier MA, Auzepy PH. Vitamin E deficiency and lipoperoxidation during adult respiratory distress syndrome. Crit Care Med. 1990;18(1):4-9.
48. Ren D, Hua Y, Yu B, Ye X, He Z, Li C, et al. Predictive biomarkers and mechanisms underlying resistance to PD1/PD-L1 blockade cancer immunotherapy. Mol Cancer. 2020;19(1):1-9.

49. Patel SP, Kurzrock R. PD-L1 expression as a predictive biomarker in cancer immunotherapy. Mol Cancer Ther. 2015;14(4):847-56.

50. Dancer RC, Parekh D, Lax S, D'Souza V, Zheng S, Bassford CR, et al. Vitamin D deficiency contributes directly to the acute respiratory distress syndrome (ARDS). Thorax. 2015;70(7):617-24.

51. Blansfield JA, Beck KE, Tran K, Yang JC, Hughes MS, Kammula US, et al. Cytotoxic T-lymphocyte-associated antigen-4 blockage can induce autoimmune hypophysitis in patients with metastatic melanoma and renal cancer. J Immunother. 2005;28(6):593.

52. Maggini S. Vitamins and minerals: contribution to immune function and health. In Dietary components and immune function. Totowa: Humana Press; 2010.

53. Calton EK, Keane KN, Newsholme P, Soares MJ. The impact of vitamin D levels on inflammatory status: a systematic review of immune cell studies. PLoS One. 2015;10(11):e0141770.

54. Donath MY, Shoelson SE. Type 2 diabetes as an inflammatory disease. Nat Rev Immunol. 2011;11(2):98-107.

55. Haffner SM. Pre-diabetes, insulin resistance, inflammation and CVD risk. Diabetes Res Clin Pract. 2003;61:S9-18.

56. Berbudi A, Rahmadika N, Cahyadi AI, Ruslami R. Type 2 diabetes 500 and its impact on the immune system. Curr Diabetes Rev. 2019; https://doi.org/10.2174/1573399815666191024085838.

57. Colombi D, Bodini FC, Petrini M, Maffi G, Morelli N, Milanese G, et al. Well-aerated lung on admitting chest CT to predict adverse outcome in COVID-19 pneumonia. Radiology. 2020:201433.

58. Wang H, Zhang L. Risk of COVID-19 for patients with cancer. Lancet Oncol. 2020;21:e181.

59. Weber J. Immune checkpoint proteins: a new therapeutic paradigm for cancer - preclinical background: CTLA-4 and PD-1 blockade. In Seminars in oncology 2010;37(5):430-439). WB Saunders.

60. Bersanelli M, Buti S. From targeting the tumor to targeting the immune system: transversal challenges in oncology with the inhibition of the PD-1/PD-L1 axis. World J Clin Oncol. 2017;8(1):3753.

61. Chambers ES, Hawrylowicz CM. The impact of vitamin D on regulatory T cells. Curr Allergy Asthma Rep. 2011;11(1):29-36.

62. Li Z, Wu M, Yao J, Guo J, Liao X, Song S, Li J, Duan G, Zhou Y, $516 \mathrm{Wu} \mathrm{X}$, Zhou Z. Caution on kidney dysfunctions of COVID19517patients. medRxiv 2020; https://doi.org/10.1101/2020.02. 08.20021212 .

63. Cheng Y, Luo R, Wang K, Zhang M, Wang Z, Dong L, et al. Kidney disease is associated with in-hospital death of patients with COVID-19. Kidney Int. 2020;97:829-38.

64. Imig JD, Ryan MJ. Immune and inflammatory role in renal disease. Compr Physiol. 2013;3(2):957-76.

65. Zhu L, Xu X, Ma K, Yang J, Guan H, Chen S, Chen Z, Chen G. Successful recovery of COVID-19 pneumonia in a renal transplant recipient with long-term immunosuppression. Am J Transplant. 2020;20(7):1859-1863.

66. Shah A, Mehta N, Reilly MP. Adipose inflammation, insulin resistance, and cardiovascular disease. J Parenter Enter Nutr. 2008;32(6):638-44.

67. Heine G, Anton K, Henz BM, Worm M. 1 $\alpha$, 25-dihydroxyvitamin D3 inhibits anti-CD40 plus IL-4-mediated IgE production in vitro. Eur J Immunol. 2002;32(12):3395-404.

68. Cuschieri J, Bulger E, Biligren J, Garcia I, Maier RV. Vitamin E inhibits endotoxin-mediated transport of phosphatases to lipid rafts. Shock. 2007;27(1):19-24.

69. Åivo J, Hänninen A, Ilonen J, Soilu-Hänninen M. Vitamin D3 administration to MS patients leads to increased serum levels of latency activated peptide (LAP) of TGF-beta. J Neuroimmunol. 2015;280:12-5. 
70.• Ramos-Martínez E, López-Vancell MR, de Córdova-Aguirre JF, Rojas-Serrano J, Chavarría A, Velasco-Medina A, et al. Reduction of respiratory infections in asthma patients supplement-

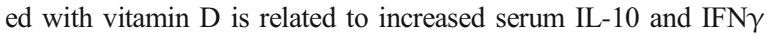
levels and cathelicidin expression. Cytokine. 2018;108:239-46 The article is of importance as it highlights supplementation of vitamin $D$ reduced respiratory infections in patients. The article is a guided support for further clinical trial to reduce inflammatory factors in COVID-19 patients as they also show respiratory failure.

71. Son EW, Mo SJ, Rhee DK, Pyo S. Vitamin C blocks TNF- $\alpha$ induced NF-kB activation and ICAM-1 expression in human neuroblastoma cells. Arch Pharm Res. 2004;27(10):1073-9.

72. Bar-El Dadon S, Reifen R. Vitamin A and the epigenome. Crit Rev Food Sci. 2017;57(11):2404-11 The article is of outstanding importance as it outlines potential role of vitamin $\mathrm{A}$ as an epigenetic modulator. It highlights that nutritional supplementations have medical benefits in health and diseases.

73. Das M, Tomar N, Sreenivas V, Gupta N, Goswami R. Effect of vitamin D supplementation on cathelicidin, IFN- $\gamma$, IL-4 and Th1/ $\mathrm{Th} 2$ transcription factors in young healthy females. Eur J Clin Nutr. 2014;68(3):338-43.

74. Sundar IK, Rahman I. Vitamin D and susceptibility of chronic lung diseases: role of epigenetics. Front Pharmacol. 2011;2:50.

75. Cantorna MT, Mahon BD. Mounting evidence for vitamin D as an environmental factor affecting autoimmune disease prevalence. Exp Biol Med. 2004;229:1136-42.

76. Suzuki YJ, Packer L. Inhibition of NF-kB activation by vitamin E derivatives. Biochem Biophys Res Commun. 1993;193:277-83.

77. Kassi E, Nasiri-Ansari N, Spilioti E, Kalotychou V, Apostolou PE, Moutsatsou P, et al. Vitamin D interferes with glucocorticoid responsiveness in human peripheral blood mononuclear target cells. Cell Mol Life Sci. 2016;73:4341-54.

78. Jeffery LE, Burke F, Mura M, Zheng Y, Qureshi OS, Hewison M, et al. 1,25-Dihydroxyvitamin D3 and IL-2 combine to inhibit T cell production of inflammatory cytokines and promote development of regulatory T cells expressing CTLA-4 and FoxP3. J Immunol. 2009;183:5458-67.

79. Tokić S, Štefanić M, Karner I, Glavaš-Obrovac L. Altered expression of CTLA-4, CD28, VDR, and CD45 mRNA in T cells of patients with Hashimoto's thyroiditis - a pilot study. Endokrynol Pol. 2017;68:274-828.

80. Tamura J, Kubota K, Murakami H, Sawamura M, Matsushima T, Tamura T, et al. Immunomodulation by vitamin B12: augmentation of CD8+ T lymphocytes and natural killer (NK) cell activity in vitamin B12-deficient patients by methyl-B12 treatment. Clin Exp Immunol. 1999;116:28-32.

81. Cippitelli M, Fionda C, Di Bona D, Di Rosa F, Lupo A, Piccoli M, et al. Negative regulation of CD95 ligand gene expression by vitamin D3 in T lymphocytes. J Immunol. 2002;168:1154-66.

82. Kramer TR, Schoene N, Douglass LW, Judd JT, Ballard-Barbash $\mathrm{R}$, Taylor PR, et al. Increased vitamin E intake restores fish-oilinduced suppressed blastogenesis of mitogen-stimulated $\mathrm{T}$ lymphocytes. Am J Clin Nutr. 1991;54(5):896-902.

83. Baeke F, Korf H, Overbergh L, van Etten E, Verstuyf A, Gysemans $\mathrm{C}$, et al. Human T lymphocytes are direct targets of 1, 25dihydroxyvitamin D3 in the immune system. J Steroid Biochem. 2010;121(1-2):221-7.

84. Morgan JW, Morgan DM, Lasky SR, Ford D, Kouttab N, Maizel AL. Requirements for induction of vitamin D-mediated gene regulation in normal human B lymphocytes. J Immunol. 1996;157(7): 2900-8.

85. Morikawa K, Nonaka M. All-trans-retinoic acid accelerates the differentiation of human B lymphocytes maturing into plasma cells. Int Immunopharmacol. 2005;5(13-14):1830-8.

86. Farhangi MA, Keshavarz SA, Eshraghian M, Ostadrahimi A, Saboor-Yaraghi AA. Vitamin A supplementation and serum Th1and Th2-associated cytokine response in women. J Am Coll Nutr. 2013;32(4):280-5.

87.• Koks S, Williams RW, Quinn J, Farzaneh F, Conran N, Tsai SJ, Awandare G, Goodman SR. Highlight article: COVID-19: Time for precision epidemiology. Exp Biol Med. 2020;245(8):677-9. The article is of outstanding importance. The suggestions provided in this article call for immediate action against considering precision epidemiology to overcome COVID-19 pandemic. It calls for intensive testing against reinfection, immunological response in individuals, and clinical prognosis against COVID19.

88. Maggini S, Wintergerst ES, Beveridge S, Hornig D. Contribution of selected vitamins and trace elements to immune function. Proc Nutr Soc. 2008;67(OCE1) E84. https://doi.org/10.1017/ S0029665108006939.

89. Buhr G, Bales CW. Nutritional supplements for older adults: review and recommendations-part I. J Nutr Elder. 2009;28(1):5-29.

Publisher's Note Springer Nature remains neutral with regard to jurisdictional claims in published maps and institutional affiliations. 